\title{
Jewish Fundamentalism in Israel
}

\author{
Israel Shahak and Norton Mezvinsky \\ London: Pluto Press, 1999. 149 pages.
}

In their book Jewish Fundamentalism in Israel, Shahak and Mezvinsky document the nature of Jewish fundamentalism and argue that it is a growing threat to Israeli society. As a work of activist scholarship, the authors point out that their aim is not to present new scholarship but to document, in English, literature that is normally available only in Hebrew, and to make the links between Jewish fundamentalism and Israeli politics clearer.

As such, this is a fascinating, informative, and easy-to-read book for anyone interested in Israeli politics, Judaism, and its relation to Israeli policies toward Palestine. It presents facets of Orthodox Judaism (particularly messianic, which they consider most dangerous) and Israeli politics not usu- 
ally available to those without access to Hebrew sources. Shahak and Mezvinsky show that Judaism, like any other religion or ideology, has its extremists and fundamentalists and that these views have very real effects on state politics and public opinion. In fact, they take a stance few are willing to risk: describing Israeli intolerance of non-Jews as Jewish Nazism. Each chapter discusses in meticulous - at times, excessive - detail the history and characteristics of particular religious groups and parties in Israel. The authors quote throughout from a diverse range of sources, from religious texts and rabbinical writings to news articles in such Israeli dailies as Ha'aretz.

In the preface, the authors lay out the book's context: "We have written this book in order to reveal the essential character of Jewish fundamentalism and its adherents. This character threatens democratic features of Israeli society." They add, furthermore: "We believe that a critique of Jewish fundamentalism, which entails a critique of the Jewish past, can help Jews acquire more understanding and improve their behavior toward Palestinians." At this point, their aim is linked primarily to prospects for peace in the Middle East, though by the end of the book their concern seems more focused on Israel itself. At the end of chapter 7, they state:

Our firm belief is that a fundamentalist Jewish regime, if it came to power in Israel, would treat Israeli Jews who did not accept its tenets worse than it would treat Palestinians. This book is an attempt to provide a wider understanding of Jewish fundamentalism and hopefully help avert the danger from becoming a reality.

After briefly outlining the key periods of Jewish history in the introduction, Shahak and Mezvinsky categorize the Israeli Jewish population into two groups: "Israel A" (the left) and "Israel B" (the right, including such religious parties as Shas). They describe the links each has with political parties in chapter 1, "Jewish Fundamentalism in Jewish Society." While both groups are described as Zionist, Israel B is shown to be sympathetic to fundamentalism while Israel A is not - and it is Israel B that is growing. They show that an affinity has developed between Likud and other secular rightwing parties with the religious parties, based on a "shared world outlook." In this sense, they suggest that there is a growing ethnic nationalism that has its roots in religious ideologies.

The two main religious groups, the Haredim and Gush Emunim, are the focus of the next chapters. Chapters 2 and 3, "Rise of the Haredim in Israel" and "The Two Main Haredi Groups," describe this group's "traditional" religious practices and its growing political influence since the 1988 political 
elections, the rise of Shas, and the pressure on Israeli politicians to become more religiously observant. Chapter 3 discusses the differences between the Ashkenazi and Sephardic (now referred to as Oriental) Jews. The latter, we are told, are more traditional and have resisted secularization, while the former are described as more secular. The hatred and violence that Shahak and Mezvinsky describe between these two groups is disturbing.

The following two chapters focus on Gush Emunim (the religious settlers), the other main religious group, and the National Religious Party that reflects their ideology. These chapters are more useful than the first two, since this group is more directly relevant to Israeli policies and the treatment of Palestinians. For example, they show that the differential treatment of Jewish and Palestinian prisoners is a policy that directly reflects Gush Emunim's position, so that "the Israeli government under both Labor and Likud leadership has refused to free Palestinian prisoners 'with Jewish blood on their hands' but has not hesitated to free prisoners 'with nonJewish blood on their hands." " In chapter 4, "The National Religious Party and the Religious Settlers," the authors describe how these settlers have impacted settlement policies in the Occupied Territories since the 1973 war, as well as Israeli Jewish religious leaders.

A critical point raised in chapter 5, "The Nature of Gush Emunim Settlements," is that because Gush Emunim supports army service (unlike the Haredim), they have been able to mainstream more into Israeli society. In their military capacity, they have been responsible for some of the worst treatment of Palestinians. Furthermore, the authors note that the state uses these settlers living in the Occupied Territories as a cheaper and more efficient buffer zone than the military. Realizing their usefulness, Gush Emunim settlers and soldiers have hampered peace efforts by refusing to withdraw from settlements during efforts to implement the Oslo accord.

The final chapters essentially expand on points raised earlier, but focus on particular events. Chapter 6, "The Real Significance of Baruch Goldstein," looks at Goldstein's career and the reactions of the Israeli government and fundamentalist Jews after his massacre of innocent worshippers in a Hebron mosque in 1994. The authors point to Goldstein's anti-Gentile and particularly anti-Arab stance - to which Israeli politicians turned a blind eye until the massacre. Shahak and Mezvinsky document the rejoicing of settlers and others upon hearing of the massacre and their making Goldstein a martyr.

Chapter 7, "The Religious Background of Rabin's Assassination," does not discuss the assassination but attempts to provide a context for it within 
Jewish history. The authors reveal that far from being an isolated individual crime, Rabin's assassination was considered justified by many Israeli Jews. They describe how, throughout Jewish history, those considered heretics or informers either have been killed, punished, or expelled. While the detailed background provided is of interest and useful in documenting that such practices have occurred, the details become excessive and cumbersome. They could have been kept shorter. The book ends with a "Note on Bibliography and Related Matters," which is in fact more like a conclusion and synthesis of the book.

For the most part, Shahak and Mezvinsky's critiques of Jewish fundamentalism are very pertinent. These links are important and must be publicized to a greater degree. Like any form of extremism, notions of superiority and self-righteousness can lead to violent practices - in this case state terrorism, apartheid, and occupation. At the same time, however, one must be cautious not to place all of Judaism under the traditions and extreme practices carried out by a minority (as is so often done with Islam). Granted, as the authors point out, it is precisely the fact that such practices are followed by a minority (a percentage of the 20 percent of Israeli Jews who are religious) and yet have such an influence on Israeli politics that they are a concern. Nonetheless, it is useful to keep in mind that Shahak and Mezvinsky write from a very strong secular perspective. Religion and tradition are contrasted with, and seen as antithetical to, their own ideals of secularism, modernity, and democracy.

Overall, however, Jewish Fundamentalism in Israel is a useful source of information about extremist religious groups in Israel and the influence they now have - and could have - on Israeli politics and society. The scope and details provided from Hebrew sources - and the authors' critical stance, which is taken by so few Israeli Jews - is important in revealing practices and attitudes that otherwise would not be made available through mainstream sources, whether scholarly or journalistic. They update and add to Shahak's previous book, Jewish History, Jewish Religion (1994), which had a similar focus. Activists engaged in the struggle for peace and justice in the Middle East, as well as scholars seeking access to alternate sources, will find this book extremely useful. 